\title{
References
}

I. Jacobson MA, O'Donnell JJ, Porteous D, Brodie HR, Feigal D, Mills J. Retinal and gastrointestinal disease due to cytomegalovirus in patients with the acquired immune deficiency syndrome: prevalence, natural history, and response to ganciclovir therapy. $Q \mathcal{F}$ Med I988; 67: 473-486.

2. Wilcox CM, Diehl DL, Cello JP, Margaretten W, Jacobson MA. Cytomegalovirus esophagitis in patients with AIDS. Ann Intern Med 1990; 113: 589-593

3. Connolly GM, Hawkins, D, Harcourt-Webster JN, Parsons PA, Husain OAN, Gazzard BG. Oesophageal symptoms, their causes, treatment, and prognosis in patients with the acquired immunodeficiency syndrome. Gut 1989; 30: 1033-1039.

\section{Kikuchi's disease associated with Epstein-Barr virus infection}

\section{Accepted for publication 2 January 1992}

Sir,

Kikuchi's disease (KD) is a cause of benign lymphadenitis known to have a worldwide distribution, reports of nearly 450 cases having been published. ${ }^{1}$ We did not know, however, of any case in Portugal until a 15 -year-old caucasian boy presented to us with pyrexia of unknown origin (PUO) and liver dysfunction.

The patient gave a 4 weeks' history of daily fever $\left(39-40^{\circ} \mathrm{C}\right)$, enlarged cervical lymph nodes, night sweats, chills, malaise, anorexia and a $4 \mathrm{~kg}$ loss of weight. He had complained of a sore throat during the first week and had developed a skin rash after a I-day course of amoxicillin. He denied any other symptoms. His epidemiological history was unremarkable. On examination he had an axillary temperature of $39^{\circ} \mathrm{C}$ and a single $3 \mathrm{~cm} \times 4 \mathrm{~cm}$, non-tender cervical lymph node and a few small supraclavicular nodes on the left side. His physical examination was otherwise unremarkable.

Laboratory investigation showed leucopenia $\left(3.45 \times 10^{9} / 1\right)$ with relative lymphocytosis $\left(\mathrm{I} \cdot 7 \times 10^{9} / \mathrm{l}\right)$, ESR of $86 \mathrm{~mm} / \mathrm{h}$ (Westergren), serum lactate dehydrogenase $(\mathrm{LDH}) \mathrm{I287} \mathrm{IU} / 1(n=\mathrm{I} 60-330 \mathrm{IU} / 1)$, serum alanine aminotransferase of $178 \mathrm{IU} / 1$ $(n=0-29 \mathrm{IU} / 1)$ and aspartate aminotransferase of $\mathrm{I} 2 \mathrm{I} \mathrm{IU} / 1(n=0-25 \mathrm{IU} / 1)$. All blood, urine stool and bone marrow bacterial cultures were negative. Acid-fast bacilli were not found in sputum, bone marrow, urine and gastric washings. His Mantoux test was negative. Bone marrow aspirate and biopsy, autoimmune studies, chest roentgenography and abdominal ultrasonography were unremarkable. Rose Bengal and Paul-Bunnell tests were negative. No yersinia antibodies were detected and toxoplasma and cytomegalovirus IgM and IgG titres were not raised. However, IgM VCA antibody to Epstein-Barr virus (EBV) was detected. During the first week in the ward the patient maintained a fever $\left(39-40^{\circ} \mathrm{C}\right)$, with progressive weight loss $(5 \mathrm{~kg})$, increased serum aminotransferases and $\mathrm{LDH}$, sustained leucopenia and relative lymphocytosis. In the second week, a biopsy of a supraclavicular lymph node showed extensive necrosis within the cortical and paracortical areas, with karyorrhectic debris and no neutrophil polymorphonuclear leucocytes. No tubercle bacilli were seen. The specimen was reported to show benign necrotising lymphadenitis, consistent with Kikuchi's disease. Treatment with naproxen (250 $\mathrm{mg}$ b.d.), resulted in prompt lysis of the fever. Four weeks later, when he was discharged, he was apyrexial, regaining weight and had resolving cervical adenopathy. His serum aminotransferase values were improving. At a 6 month follow-up he was well, had no adenopathy and his aminotransferases were normal.

Kikuchi's disease is probably misdiagnosed in our country, and therefore, the clinical manifestations of this benign lymphadenitis should be more widely known and lymph node biopsy more readily performed. Kikuchi's disease with abnormal liver 
function tests ${ }^{1-4}$ and $\mathrm{PUO}^{3-5}$ has been described recently. We suggest, as Bailey et al. ${ }^{3}$ and Pearl and Strauchen ${ }^{5}$ have done, that $\mathrm{KD}$ must be considered a potential cause of PUO. Our patient's illness resolved following treatment with naproxen which is as Kapadia et $a l .{ }^{4}$ described, but why this drug is effective is not understood. The aetiology of the disease remains uncertain but an association with yersinia, ${ }^{4,6}$ toxoplasma, ${ }^{7}$ herpes virus $6,{ }^{6} \mathrm{EBV},{ }^{8}$ and more recently human immunodeficiency virus $^{9}$ and parvovirus B I $9^{1}$ infections has been suggested. Like Rivano et al., ${ }^{8}$ we found an association with the Epstein-Barr virus.

Department of Infectious Diseases,

University Hospital and

School of Medicine,

Coimbra,

Portugal

\author{
Eduardo M. Rabadão* \\ foaquim F. Oliveira \\ Saraiva da Cunha \\ Rui Côrte-Real
}

* Address correspondence to: Dr E. M. Rabadão, Clinica de Doenças Infecciosas, Hospital da Universidade, 3049 Coimbra Codex, Portugal.

\title{
References
}

I. Meyer $\mathrm{O}$, Ribard $\mathrm{P}$, Belmatoug $\mathrm{N}$ et al. Trois cas de lymphadénite de Kikuchi au cours du lupus erythémateux systémique. Rôle du parvovirus BI9. Ann Méd Intern I99I ; I42(4): 259-264.

2. Ohta A, Matsumoto Y, Ohta, T et al. Still's disease associated with necrotizing lymphadenitis (Kikuchi's disease): report of 3 cases. F Rheumatol 1988; 15:981-983.

3. Bailey EM, Klein NC, Cunha AB. Kikuchi's disease with liver dysfunction presenting as fever of unknown origin (letter). Lancet I989; ii : 986.

4. Kapadia V, Robinson BA, Helen HB. Kikuchi's disease presenting as fever of unknown origin (letter). Lancet 1989; ii : 1519-1520.

5. Pearl D, Strauchen JA. Kikuchi's disease as a cause of fever of unknown origin (letter). $N$ Engl f Med I989; 320(17): I I 47-I I 48 .

6. Feller AC, Lennert $\mathrm{K}$, Stein $\mathrm{H}$ et al. Immunohistology and etiology of histiocytic necrotizing lymphadenitis: report of three instructive cases. Histopathology 1983; 7 : 825-839.

7. Kikuchi $M$, Yoshizumi $T$, Nakamura $H$. Necrotizing lymphadenitis: possible acute toxoplasmic infection. Virchows Arch $(A)$ 1977; 376: 247-253.

8. Rivano MT, Falini B, Stein $\mathrm{H}$ et al. Histiocytic necrotizing lymphadenitis without granulocytic infiltration (Kikuchi's lymphadenitis). Morphological and immunohistochemical study of eight cases. Histopathology 1987; II : 1013-1027.

9. Pileri SA, Sabattini E, Costigliola P et al. Kikuchi's lymphadenitis and HIV infection. $A I D S$ I99I; 5(4): 459-46I.

\section{Gemella morbillorum endocarditis in an intravenous drug abuser}

\author{
Accepted for publication 19 December $199 \mathrm{I}$
}

Sir,

Gemella species rarely cause infective endocarditis. We wish to report a case of endocarditis caused by Gemella morbillorum. There appear to be only two previous reports of endocarditis caused by G. morbillorum, formerly Streptococcus morbillorum in the U.K. ${ }^{1}$ Streptococcus morbillorum was recently transferred to the genus Gemella as a result of DNA homology studies. ${ }^{2}$

A I9-year-old male intravenous drug abuser presented in October I990 with a 2 weeks' history of malaise, night sweats and intermittent fever. He had started injecting heroin at the age of 14 years. Since then, he had been on various drug rehabilitation schemes, all unsuccessful. In the months before his admission to hospital, he had been 